\title{
O TRABALHO ESCRAVO CONTEMPORÂNEO: ALCANCE CONCEITUAL NA VISÃO DOS TRIBUNAIS SUPERIORES BRASIEIROS
}

\author{
Felipe Marquette de Sousa ${ }^{1}$ \\ Jessica Rotta Alves ${ }^{2}$
}

\begin{abstract}
Resumo: Não obstante todo o sistema de proteção ao trabalhador na seara jurídica nacional ou internacional, de ordem Constitucional ou Infraconstitucional, o Brasil ainda enfrenta um problema recorrente: a existência de trabalho escravo. Diferentes termos, expressões e adjetivos são comumente utilizados pelos estudiosos para configurar práticas e situações aviltantes de trabalho. O objetivo do presente estudo é trazer à reflexão o posicionamento dos Tribunais Superiores Brasileiros acerca do tema e o alcance conceitual. A metodologia constitui-se de análise jurisprudencial complementada por produções científicas de livros e revistas especializadas. Interpretação ampla da caracterização do trabalho escravo é o entendimento do Tribunal Superior do Trabalho e do Superior Tribunal de Justiça, principalmente quando a situação afronta a individualidade e a dignidade do trabalhador. A visão restritiva que era comum no Supremo Tribunal Federal, tornou-se mais ampla a partir de 2012, concorrendo para uma uniformização da jurisprudência.
\end{abstract}

Palavras-chave: Trabalho escravo; Interpretação; Tribunais Superiores.

\footnotetext{
${ }^{1}$ Faculdade de Direito/Universidade do Vale do Paraíba, Brasil. E-mail: felipe_marquette@hotmail.com.

2 Faculdade de Direito/Universidade do Vale do Paraíba, Brasil. E-mail: je.rotta@hotmail.com.
} 